\title{
Struktura militarnego krajobrazu pozycji umocnionej z drugiej wojny światowej na przykładzie wybranych odcinków Pozycji Pomorskiej
}

\author{
Michał Kupiec \\ https://orcid.org/0000-0003-0850-6105 \\ Wydział Nauk Ścisłych i Przyrodniczych, Uniwersytet Szczeciński
}

\section{Magda Olejniczak}

https://orcid.org/0000-0002-6573-1280

Wydział Nauk Ścisłych i Przyrodniczych, Uniwersytet Szczeciński

Zarys treści: W pracy przedstawiono próbę odtworzenia pełnej pierwotnej struktury fragmentów Pozycji Pomorskiej w jej finalnej postaci z wiosny 1945 r. na podstawie dostępnych materiałów oraz prac terenowych. Pozycja ta ma w krajobrazie kulturowym Pomorza szczególną wartość historyczną i krajobrazową ze względu na ścisły związek przebiegu Wału Pomorskiego (Pommernstellung) z uwarunkowaniami fizjografii oraz różnorodność możliwych do zidentyfikowania reliktów.

Słowa kluczowe: Wał Pomorski, Pozycja Pomorska, Pommernstellung, Pomorze Zachodnie, fortyfikacja, struktura fortyfikacji, krajobraz kulturowy, krajobraz militarny

Budowle obronne, fortyfikacje o różnej formie i układzie przestrzennym towarzyszą człowiekowi od najdawniejszych lat. Poprzez wieki przybierały one różne formy, w zależności od pełnionych funkcji, lokalizacji i postępu technicznego ${ }^{1}$. Krajobraz militarny stanowi specyficzny wariant krajobrazu kulturowego, w którym obiekty fortyfikacyjne podporządkowane są przestrzennie wymaganiom obowiązującej doktryny obronnej. Ponieważ wraz z rozwojem techniki wojskowej realia pola walki ulegały szybkim przemianom, modyfikowano również elementy struktury krajobrazu militarnego związane z fortyfikacjami. Krajobrazy militarne powstawały również

${ }^{1}$ L. Klupsz, Miejsce fortyfikacji we wspótczesnych aglomeracjach, w: Fortyfikacje w przestrzeni miast, red. A. Wilkaniec, M. Wichrowski, Poznań 2006.
Abstract: The paper presents an attempt of reconstructing the full, original structure of fragments of the Pomeranian Position in its final form from spring 1945, based on available materials and field works. This position in the cultural landscape of Pomerania has a special historical and landscape value due to the close relationship between the course of the Pommernstellung and physiographic conditions and the variety of identifiable relics.

Keywords: Pomeranian Position, Pommernstellung, Western Pomerania, fortification, fortification structure, cultural landscape, military landscape

w konkretnym kontekście geopolitycznym, który ulegał równie dynamicznym przemianom jak założenia taktyczno-techniczne. Dlatego też współczesne krajobrazy militarne można traktować jako swoisty palimpsest świadczący o obiektach i założeniach przestrzennych charakterystycznych dla poszczególnych epok i uwarunkowań historycznych ${ }^{2}$. W krajobrazie kulturowym w rozumieniu nauk geograficznych ${ }^{3}$ dość rzadko napotyka się w terenie układy przestrzenne o podłożu militarnym, które w całości można nazwać krajobrazem militarnym (zespołem obiektów tworzących

\footnotetext{
R. Woodward, Military landscapes: Agendas and approaches for future research, „Progress in Human Geography”, 38 (1), 2014, s. 40-61.

${ }^{3}$ U. Myga-Piątek, Krajobrazy kulturowe. Aspekty ewolucyjne itypologiczne, Katowice 2012.
} 
przemyślaną strukturę, determinujących specyficzny sposób zagospodarowania i użytkowania terenu, zasięgi widoczności itp.). Są to raczej pojedyncze formy lub zespoły obiektów o charakterze reliktowym, umożliwiające odtworzenie dawnego założenia krajobrazowego. Inną cechą krajobrazów fortecznych, rozumianych jako rodzaj krajobrazów militarnych, jest ich efemeryczność. Powstawały w celu wypełnienia założeń konkretnej doktryny militarnej i uwarunkowań taktyczno-technicznych, a gdy to zrobiły (a częściej, gdy założenia te okazały się błędne lub przestarzałe), zwykle porzucano je lub przebudowywano, a forma i struktura krajobrazu militarnego była przekształcana lub zacierana ${ }^{4}$. Współczesne relikty krajobrazów militarnych są więc raczej dokumentem myśli architektonicznej, technicznej i inżynieryjnej, zaświadczając historię przekształcania krajobrazu na potrzeby wojenne. Nie są już natomiast krajobrazami w ujęciu funkcjonalnym.

\section{Militarny i forteczny krajobraz kulturowy}

W polskiej literaturze pojęcie krajobraz militarny używane jest często zamiennie ze sformułowaniami krajobraz forteczny czy krajobraz warowny. Najbardziej rozpowszechnione jest to ostatnie, wprowadzone do języka polskiego na przełomie lat siedemdziesiątych i osiemdziesiątych $\mathrm{z}$ inicjatywy prof. Janusza Bogdanowskiego. Odpowiada ono niemieckiemu Wehrlandschaft i angielskiemu strategic landscape, oznaczając całościową postać ukształtowania i pokrycia terenu, który został świadomie wybrany i przystosowany do celów obronnych. Jest to rozszerzenie terminu architectura militaris, utożsamianego z budowlami, uzbrojeniem i wyposażeniem obiektów bojowych. Krajobraz warowny uwzględnia również wszelkie niebojowe

\footnotetext{
${ }^{4}$ G. Kiarszys, Erased landscapes: conflict, memory and post-World War II landscape transformation in western Poland, w: Conflict landscapes and archeology from above, ed. B. Stichelbaut, D. Cowley, Dorchester 2016, s. 219-235.
}

budowle i urządzenia, które służą obronie, w tym zieleń (maskującą, przeszkodową, użytkową i ozdobna) oraz podziały gruntowe, m.in. wynikające z systemu ograniczeń budowlanych kształtujących strukturę urbanistyczną, a także powiązania ogniowe i sygnalizacyjne, które przekładają się dziś na powiązania widokowe 5 .

Rachel Woodward opisuje krajobraz militarny jako „przestrzenie i miejsca, w których znaki imperatywów militarnych manifestują się w formie materialnej i które można odczytać, aby zrozumieć działanie takich imperatywów"6. Jest to więc pojęcie nieco szersze, wykraczające poza fortyfikacyjny, obronny charakter obiektów. Można zatem włączać do struktury krajobrazów militarnych takie obiekty jak zespoły koszarowe i poligonowe, cmentarze wojskowe, pomniki i inne formy upamiętnień, układy komunikacyjne o funkcji militarnej itp. Inaczej mówiąc, jest to obszar, którego charakter wynika z pośredniej i bezpośredniej aktywności militarnej o bardzo zróżnicowanym charakterze. Cechą wyróżniającą krajobrazy militarne jest ukształtowanie historyczne wynikające z ówczesnych decyzji administracyjnych, które wpływały na strukturę własności i użytkowania terenu, oraz fizyczne kształtowanie krajobrazu w otoczeniu dzieł obronnych poprzez prace inżynieryjne i czynności prowadzące do pokrycia zielenią dzieł obronnych i otaczających je terenów ${ }^{7}$.

W Polsce podobny sposób opisu i analizy krajobrazu kulturowego zaproponował m.in. Bogdanowski ${ }^{8}$, a bogactwo i zróżnicowanie zasobu obiektów fortecznych

\footnotetext{
5 J. Środulska-Wielgus, K. Wielgus, Waloryzacja jako podstawa turystycznego udostępnienia krajobrazu warownego, „Przestrzeń i Forma”, 26, 2016, s. $375-390$.

${ }^{6}$ R. Woodward, Looking at military landscapes: Definitions and approaches, w: The evolving boundaries of defence. An assessment of recent shifts in defence activities, ed. R. Bellais, Emerland, 2014 (Contributions to Conflict Management. Peace Economics and Development, 23), s. 141-155.

Ramowy Program Ochrony i Rewitalizacji Zespołu Historyczno-Krajobrazowego Twierdzy Kraków, Kraków 2006, załącznik do uchwały Rady Miasta Krakowa Nr CXIX/1294/06 z 25 października 2006 r.

8 J. Bogdanowski, Architektura obronna w krajobrazie Polski, Warszawa 2002.
} 
w kraju znajdują odzwierciedlenie w bardzo bogatej literaturze przedmiotu. Autorzy poruszający interesującą nas problematykę zajmują się zarówno opisem struktur i rozwiązań technicznych ${ }^{9}$, jak i możliwościami ich współczesnego wykorzystania i udostępniania, renowacji i rekonstrukcji ${ }^{10}$.

Na początku XX w. wskutek zmian doktryny wojennej wynikających z błyskawicznego postępu techniki i rozwoju artylerii dawne zespoły forteczne w formie twierdz zaczęto uważać za przestarzałe. Przekonanie o ich słabości utwierdziły doświadczenia pierwszej wojny światowej, dlatego fortyfikacje zaczęły przybierać formę niewielkich, rozproszonych i świetnie ukrytych w terenie obiektów, które łączono naziemnymi i podziemnymi liniami komunikacyjnymi, tworząc w ten sposób wzdłuż granic ciągłe linie obronne ${ }^{11}$. Strukturę takich pozycji, tzn. rozmieszczenie i powiązania założeń obronnych, dyktowały warunki terenowe. Wiek XX przyniósł też jednak wykorzystanie celowego przekształcenia krajobrazu: poprzez prace ziemne i inżynieryjne upodabniano obiekty do krajobrazu naturalnego, stosując również na szeroką skalę system maskowania i starając się maksymalnie wykorzystać istniejące uwarunkowania terenu ${ }^{12}$. Działania te miały dezinformować przeciwnika co do istnienia elementów i zespołów militarnych, ich położenia, formy, funkcji i znaczenia. Nie zaniechano przy tym utrzymywania dawnych obiektów fortowych. Ciężka fortyfikacja stała wychodziła naprzeciw wyzwaniom wojny pozycyjnej, natomiast

${ }^{9}$ D. Chylińska, Fortyfikacje nowożytne jako element krajobrazu kulturowego na przykładzie Międzyrzeckiego Rejonu Umocnionego, „Problemy Ekologii Krajobrazu", 18, 2006, s. 379-387; A. Marek, Ł. Marszałek, Obiekty militarne jako element krajobrazu kulturowego Pótwyspu Helskiego, „Studia z Geografii Politycznej i Historycznej", 7, 2018, s. 233-249.

${ }^{10}$ D. Chylińska, Nowożytne fortyfikacje state - wybrane problemy zagospodarowania turystycznego, ,Turystyka i Rekreacja”, 2, 2006, s. 52-63; W. Cudny, R. Rouba, Hotelarstwo jako sposób na rewitalizację zabytkowych obiektów militarnych pochodzących z XIX IXX wieku, ,Ochrona Zabytków”, 3-4, 2012, s. 107-122.

11 J. Bogdanowski, Architektura, s. 164-178.

${ }^{12}$ R. Bochenek, Od muru chińskiego do linii Maginota, Warszawa 1964. fortyfikacja stała lekka oraz polowa miały sprostać przestrzennej dynamice wojny manewrowej ${ }^{13}$.

Jednym z przykładów linii obronnych powstałych w latach międzywojennych jest Pozycja Pomorska (Pommernstellung), zwana również Wałem Pomorskim. Stanowi ona rozległy system fortyfikacji budowany przez Niemców w latach 1932-1944, początkowo w związku z zagrożeniem wojną z Polską, a w latach drugiej wojny światowej - jako kolejna linia obronna przesuwającego się na zachód frontu wschodniego $^{14}$. Charakteryzuje ją dobrze zachowany system obronny, złożony $\mathrm{z}$ wzajemnie uzupełniających się i współpracujących elementów, osadzony w zróżnicowanym krajobrazie młodoglacjalnym i świetnie wykorzystujący uwarunkowania fizycznogeograficzne. Przebieg linii zaprojektowano wzdłuż wyróżniających się wyraźnymi krawędziami form terenowych, jak rynny dolin rzecznych (m.in. Piławy i Drawy) oraz ciąi jezior czy obszarów podmokłych. Wykorzystano też zalety pokrycia terenu, wybierając ciagi obszarów leśnych. Starannie wybrano lokalizację blokad szlaków komunikacyjnych oraz polnych ciaśnin na obszarach lasów. W pierwotnym założeniu konstrukcja ta miała służyć jedynie krótkotrwale, jednak uzupełnienie o system fortyfikacji polowych z 1944-1945 r. sprawiło, że jest dziś bardzo dobrze zachowanym przykładem krajobrazu warownego z końcowego okresu drugiej wojny światowej. Odzwierciedla on dziedzictwo kulturowe europejskiej sztuki fortyfikacyjnej, będąc jednocześnie ważnym elementem lokalnej świadomości historycznej i charakterystycznym składnikiem kulturowego krajobrazu Pomorza.

W naukach o krajobrazie można wyróżnić dwa dominujące wątki tematyczne: badania nad funkcją krajobrazu oraz jego

\footnotetext{
${ }^{13}$ D. Piasecki, J. Ellwart, Wat Pomorski, Gdynia 2014.

14 J.E. Kaufmann, H.W. Kaufmann, R.M. Jurga, Fortyfikacje Trzeciej Rzeszy. Niemieckie umocnienia i systemy obronne w II wojnie światowej, Poznań 2014
} 
percepcją ${ }^{15}$. Poza skupieniem się na aspektach związanych z postrzeganiem zjawisk w krajobrazie te dwie grupy problemów badawczych używają odmiennych metod i aparatu pojęciowego. Celem prezentowanej publikacji jest analiza funkcjonalna przypadku krajobrazu militarnego z drugiej wojny światowej za pomocą metod wywodzących się z analizy geograficznej; nie był tu natomiast brany pod uwage aspekt percepcyjny.

Artykuł prezentuje analizę struktury wybranych odcinków Pozycji Pomorskiej przeprowadzoną na podstawie zachowanych w terenie reliktów krajobrazu fortecznego. Rozmieszczenie obiektów przeanalizowano zarówno w kontekście założeń działania systemu obronnego, jak i uwarunkowań fizjograficznych. Wykorzystując metody analizy archiwalnych materiałów kartograficznych, badania terenowe oraz dane teledetekcyjne, odtworzono wciąż czytelne we współczesnym krajobrazie kulturowym założenia oryginalnego systemu obronnego.

\section{Metodyka}

Do badania elementów struktury militarnej krajobrazu kulturowego Pozycji Pomorskiej wybrane zostały trzy fragmenty stanowiące cztery odcinki fortyfikacyjne (ryc. 1). Selekcja podyktowana została zróżnicowaniem fizjograficznym, które wpłynęło na sposób zaplanowania obrony, a co za tym idzie - na stopień rozbudowania i zróżnicowania elementów krajobrazu militarnego. Wybrano tu odcinki prezentujące raczej typową strukturę:

- Groß Karzenburg (Sępólno Wielkie) oznaczenie kodowe Karz.,

- Demmin (Dyminek) - oznaczenie kodowe De.,

- Salmer Theerofen (Pustelnia) i Salmer Theerofen Krähenfließ (Pustelnia Kanał) - oznaczenia kodowe STF i STK.

\footnotetext{
15 J. Plit, Krajobrazy kulturowe Polski i ich przemiany, Warszawa 2016 (Prace Geograficzne, 253).
}

W badanych odcinkach dokonano inwentaryzacji i zestawienia obiektów stałych (żelbetowych) oraz elementów fortyfikacji polowej. Analizy struktury fortyfikacji polowych oraz identyfikacji większości obiektów dokonywano w oparciu o wizualizację przetworzonego modelu terenu. Wykorzystane zostały w tym celu model LRM (local relief model) ${ }^{16}$ oraz analiza cieniowania (analytical hillshading) modelu terenu wykonanego na podstawie chmury punktów LiDAR ${ }^{17}$ pozyskanych w projekcie ISOK przez GUGiK. Analizę materiałów cyfrowych uzupełniono dzięki pracom terenowym umożliwiającym w wielu przypadkach weryfikację identyfikacji obiektów oraz ocenę stanu ich zachowania. Wykorzystano również szereg prac inwentaryzacyjnych wykonanych wcześniej przez innych autorów ${ }^{18}$. Struktura obiektów wizualizowana była poprzez budowę bazy danych w oprogramowaniu QGIS. Wykorzystano szereg narzędzi GIS, umożliwiających m.in. odtworzenie osi strzelnic, analizę pól ostrzału czy wyliczenie danych statystycznych dotyczących zidentyfikowanych obiektów. Analiza pokrycia terenu sektorami ostrzału ze stanowisk żelbetowych prowadzona była w strefie ekwidystanty $1 \mathrm{~km}$ od przebiegu pierwszej linii obrony. Wybrana ekwidystanta nie ilustruje zasięgu skutecznego ognia, który na terenach leśnych był na pewno mniejszy, a na otwartych i przy użyciu ognia pośredniego - zdecydowanie większy. Odległość jednego kilometra wybrano raczej w celu czytelnego ukazania złożonego systemu nakładających się pól ostrzału.

\footnotetext{
${ }_{16}$ R. Hesse, LiDAR-derived Local Relief Models - a new tool for archeological prospection, „Archeological Prospection”, 17 (2), 2010, s. 67-72.

${ }_{17}$ G. Kiarszys, Ł. Banaszek, Dostrzec i zrozumieć. Porównanie wybranych metod wizualizacji danych ALS wykorzystywanych w archeologii, „Folia Praehistorica Posnaniensia", 22, 2017, s. 233-270.

18 J. Miniewicz, B. Perzyk, Wat Pomorski, Warszawa 1997; B. Perzyk, Inwentaryzacja, waloryzacja i wytyczne do programu ochrony fortyfikacji Wału Pomorskiego w granicach woj. zachodniopomorskiego, [b.m.w.] 2001, mps, Zachodniopomorski Wojewódzki Konserwator Zabytków; K. Michalak, J. Wajda, Fortyfikacje Pozycij Pomorskiej jako walor kulturowy Drawieńskiego Parku Narodowego, „Nadwarciański Rocznik Historyczno-Archiwalny”, 18, 2011, s. 131-150.
} 
By dokonać porównania struktury umocnień, wyliczono tutaj szereg parametrów geostatystycznych:

- długość linii obrony odcinka, rozumianą jako długość przebiegu pierwszej linii obrony;

- sumę długości wszystkich rowów strzeleckich;

- współczynnik rozwinięcia, rozumiany jako stosunek sumy długości wszystkich odcinków rowów strzeleckich do długości linii obrony odcinka;

- gęstość stałych obiektów fortecznych na $1 \mathrm{~km}$ linii obrony;

- liczbę polowych obiektów fortyfikacyjnych (w tym stanowisk PAK $^{19}$ );

- podstawowe statystyki najbliższego sąsiedztwa: oczekiwaną i rzeczywistą odległość od najbliższego sąiada (expected/ observed nearest neighbour) oraz wskaźnik najbliższego sąsiedztwa (nearest neighbour index - NNI) ${ }^{20}$.

\section{Pozycja Pomorska}

Decyzję, na mocy której na Pomorzu miały powstać nowe fortyfikacje, podjęto pod koniec $1930 \mathrm{r}$. W założeniu twórców była to tylko pozycja umocniona, tj. rozbudowana pozycja polowa osłaniająca rejony koncentracji wojsk i Pomorze Zachodnie w razie uderzenia wojsk polskich. Realizację projektu rozpoczęto od robót terenowych, studiów operacyjnych i prac kartograficznych. Przeznaczenie na ten cel niewielkich środków finansowych powodowało, że przebieg linii miał się opierać na ukształtowaniu terenu i przeszkodach naturalnych. Fortyfikację budowano etapami. Najpierw ryglowane były główne, najbardziej zagrożone kierunki operacyjne $\mathrm{z}$ najmniejszą liczbą przeszkód naturalnych. Budowę pierwszego etapu umocnień rozpoczęto w 1932 r., równolegle ze

\footnotetext{
${ }^{19}$ PAK (Panzerabwehrkanone) - stanowisko działa przeciwpancernego.

${ }^{20}$ K. McGarigal, S.A. Cushman, E. Ene, FRAGSTATS: Spatial Pattern Analysis Program for Categorical and Continuous Maps, „UMass Landscape Ecology Lab" (http://www.umass.edu/landeco/research/fragstats/fragstats.html, dostęp: 7 maja 2020).
}

wznoszeniem przeszkód i zapór oraz regulacją Piławy ${ }^{21}$. By zachować realizację projektu w tajemnicy, pozorowano działania kartograficzne, melioracyjne, inżynieryjne oraz remonty dróg. W 1934 r. przystąpiono do kontynuacji prac, tym razem na dużą skalę. W miejscach kluczowych pod kątem defensywy budowane były grupy warowne zdolne do długotrwałej samodzielnej obrony, choć w przypadku obiektów Pozycji Pomorskiej nazywanie ich grupami wydaje się nieco na wyrost. Zaczęto również stosować kamuflaż: rozpinane były siatki maskujące, sadzona zieleń maskująca, wznoszone schrony przypominające budynki itp. W latach 1935-1936 zintensyfikowano prace przy budowie nowych fortyfikacji i zagęszczano odcinki wzniesione wcześniej. W 1937 r. kontynuowane były prace przy schronach ciężkich i podziemiach. Największy wysiłek budowlany skoncentrowano nad Notecią. W latach 1938-1939, aż do zakończenia mobilizacji przeciwko Polsce, trwały prace wykończeniowe przy schronach bojowych ${ }^{22}$. W następnych latach umocnienia te straciły jednak znaczenie strategiczne. Po zwycięskim zakończeniu kampanii wrześniowej umocnienia Pozycji Pomorskiej zostały opuszczone i zakonserwowane, tak aby mogły posłużyć w kolejnych działaniach wojennych. Już w trakcie wojny zdemontowano $\mathrm{z}$ nich jednak część wyposażenia na potrzeby innych pozycji obronnych, m.in. Wału Atlantyckiego.

Zasadniczy kształt krajobrazowy linia umocnień Pozycji Pomorskiej uzyskała w toku alarmowej rozbudowy pozycji polowych zimą 1944/1945 r., w obliczu szybko zbliżającego się frontu. Obiekty żelbetowe uzupełniono wówczas złożoną strukturą fortyfikacji polowych różnego typu i przeznaczenia, wykonywanych

\footnotetext{
S. Sabien, Pierwszy etap budowy Pozycji Pomorskiej w świetle dokumentów z federalnego archiwum wojskowego we Freiburgu, „Cztery Historie”, 1 (2), 2015, s. 50-59.

${ }_{22}$ M. Dudek, J. Sadowski, Fortyfikacje Wału Pomorskiego w Wałczu, Gliwice 2006.
} 


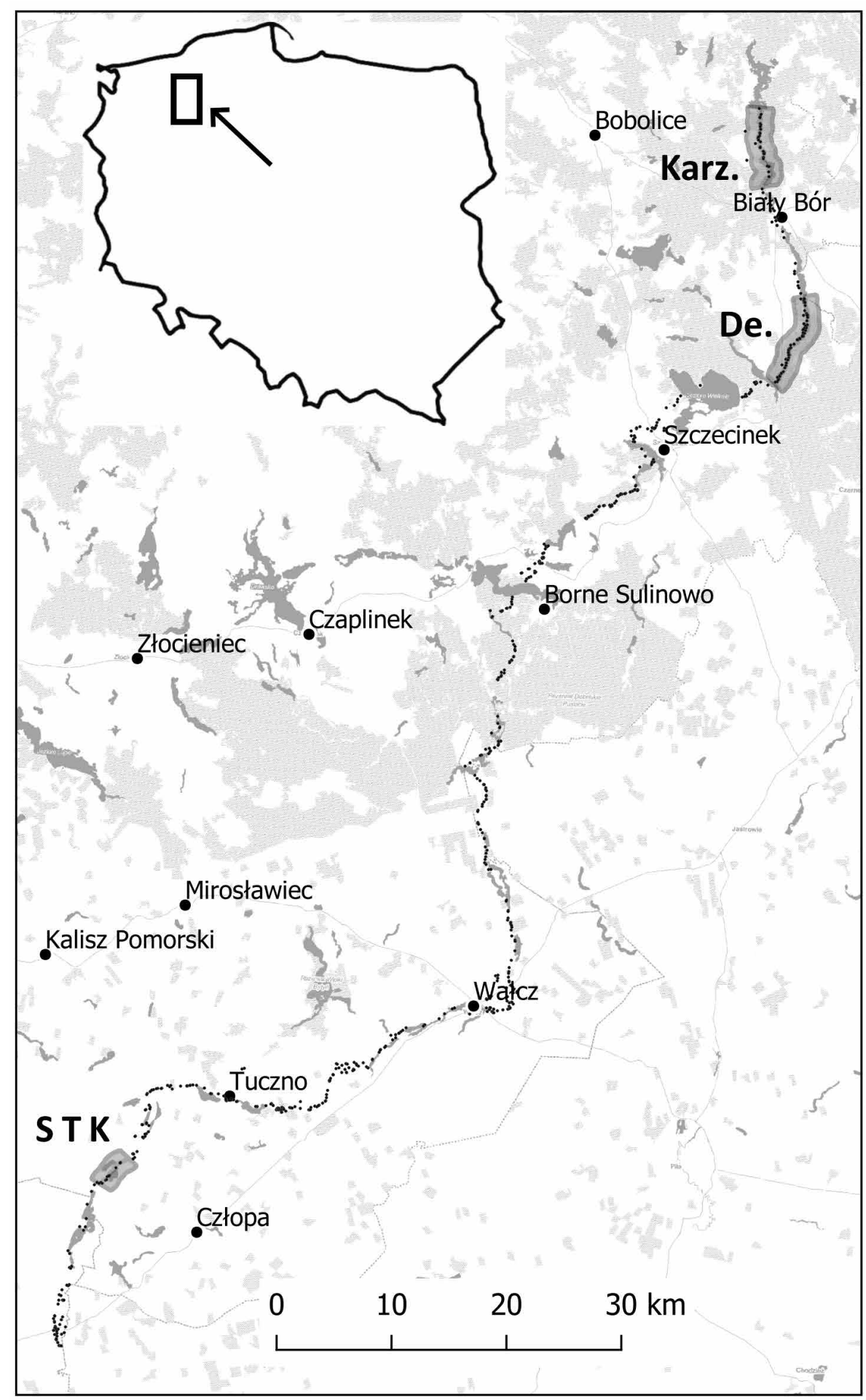

Ryc. 1. Położenie badanych odcinków na tle przebiegu Pozycji Pomorskiej.

Żródło: oprac. własne z wykorzystaniem danych „Open Street Map” 
siłami mieszkańców, robotników przymusowych, kadetów szkół wojskowych oraz samego wojska. Linię już istniejących schronów uzupełniono o fortyfikacje polowe obejmujące 2-3 linie okopów, stanowiska ogniowe artylerii, ziemianki i rowy przeciwpancerne. Zbudowano również szereg nowych żelbetowych stanowisk broni maszynowej typu ringstand (tobruk, Rs58c). W istniejących schronach uzupełniane były sprzęt i uzbrojenie, zakładano bowiem, że pozycja powinna zatrzymać nacierające wojska przez co najmniej czternaście dni, aż do nadejścia posiłków z głębi kraju. Od 1944 r. do nadciągnięcia rosyjskich i polskich wojsk szybko uzupełniano Pozycję Pomorską i próbowano ją dostosować do przyszłych zadań. W obliczu zmian na polu walki w końcowych latach wojny okazała się jednak przestarzała, słaba i niedostatecznie obsadzona. Wiele odcinków najprawdopodobniej nie obsadzono w ogóle, a często brakowało również wyposażenia obiektów. W toku walk obserwowano też zresztą wielokrotnie, że obrońcy woleli przebywać poza schronami niż w środku ${ }^{23}$. Na początku stycznia $1945 \mathrm{r}$. Sowieci rozpoczęli ofensywę, która doprowadziła m.in. do zdobycia Pomorza. Pozycja Pomorska przełamana została siłami 1 Frontu Białoruskiego między 28 stycznia a 28 lutego 1945 r., po ciężkich i krwawych walkach, w których wzięła też udział 1 Armia Ludowego Wojska Polskiego ${ }^{24}$.

Od razu po zdobyciu pozycji polscy i radzieccy saperzy niszczyli fortyfikacje. W latach pięćdziesiątych przeprowadzono z kolei demontaż i złomowanie elementów pancernych. Część transzei, okopów i rowów przeciwpancernych przebiegających przez pola zostało zasypane i zaorane. Po wojnie doszło do znaczącej zmiany struktury użytkowania terenu. Na pojeziernym obszarze Pomorza szczególnie znacząco

\footnotetext{
${ }^{23}$ E. Murawski, Bój o Pomorze. Ostatnie walki obronne na wschodzie, Oświęcim 2016.

${ }^{24}$ A. Golczewski, Wyzwolenie Pomorza Zachodniego w roku 1945, Poznań 1971.
}

zwiększył się udział lasów, które nasadzano kosztem pól uprawnych ${ }^{25}$. Ponadto zniszczeniu ulegały często systemy melioracyjne i regulacyjne w dolinach rzecznych, wskutek czego w doliny, których krawędziami przebiegała linia umocniona, powróciły lasy łęgowe oraz wtórne zabagnienie ${ }^{26}$. Zalesienie zakonserwowało czytelne ślady obiektów polowych, dzięki czemu na większości przebiegu dawnej linii umocnionej relikty krajobrazu militarnego zachowały się w niezłym stanie do dziś.

Obecnie trwają prace nad ochroną, zachowaniem i zagospodarowaniem poniemieckich fortyfikacji. Przykładami są zaadaptowane pod kątem turystyki obiekty w Wałczu, Białym Borze czy Szczecinku $(B$-Werk). O potencjale turystycznym obiektów związanych z dawną Pozycją Pomorską świadczą również inne waloryzacje $^{27}$ oraz inicjatywy społeczności lokalnych.

\section{Uwarunkowania terenowe}

Prace nad budową Pozycji Pomorskiej poprzedzone zostały wieloletnimi studiami terenowymi. Plany zaprojektowano na szczegółowych mapach topograficznych, zgodnie z ówczesną koncepcją obronną Niemiec, zakładającą obronę newralgicznych części kraju w oparciu o przeszkody naturalne i rzeźbę terenu. $Z$ ekonomicznego punktu widzenia wymagało to poświęcenia mniejszych nakładów finansowych i krótszego czasu. Obiekty militarne Wału Pomorskiego rozlokowano więc w urozmaiconym terenie, wykorzystując uwarunkowania topograficzne do ich maskowania oraz wytyczenia przebiegu linii rowów strzeleckich i przeszkód przeciwpancernych. System obrony oparto o strefy

\footnotetext{
${ }_{25}$ P. Pieńkowski, M. Podlasiński, Changes in forest cover of Szczecin Lowland from the $16^{\text {th }}$ to the end of the $20^{\text {th }}$ century, in relation to soil cover, ,Electronic Journal of Polish Agricultural Universities. Series: Forestry", 5 (2), 2002.

${ }^{26}$ M. Kupiec, Przemiany krajobrazowe wybranych dolin rzecznych w Polsce Pótnocno-Zachodniej od XIX do początków XXI wieku, Szczecin 2014.

${ }^{27}$ M. Kupiec, E. Dusza, Potencjat turystyczny obiektów związanych z dawną Pozycją Pomorską, ,Problemy Ekologii Krajobrazu”, 34, 2002, s. 149-155. J. Miniewicz, B. Perzyk, Wat.
} 
wzgórz morenowych i doliny rzek. Obecność licznych jezior morenowych umożliwiała kanalizowanie potencjalnych osi natarcia, co wykorzystano poprzez ufortyfikowanie licznych wąskich przesmyków. W porównaniu z pozostałą częścią Pomorza Zachodniego panują tutaj najbardziej surowe warunki klimatyczne: średnie temperatury roczne są najniższe, a zimy śnieżne i dość mroźne, co umożliwia zamarzanie cieków i zbiorników wodnych, a co za tym idzie - łatwiejsze przemieszczanie wojsk; jednocześnie odnotowywane są najwyższe sumy opadów atmosferycznych, które powodują powstawanie trudnych do przebycia latem bagien i rozlewisk.

Ukształtowanie Pomorza Zachodniego narzucało konkretne rozwiązania obronne. Bryły schronów zaplanowano tak, by miały obniżoną sylwetkę (kazamaty pancerne) i były wpasowane w zarys istniejących form terenu czy schowane na przeciwstokach. Istotną przeszkodę terenową stanowiły biegnące kilometrami wysokie i strome skarpy dolin rzecznych oraz brzegi jezior rynnowych. Narysy i przebieg fortyfikacji polowych dostosowywano do ukształtowania terenu oraz założeń taktycznych, tak aby przy minimalnych nakładach finansowych uzyskać najbardziej efektywną linię obrony, wymagającą do obsady możliwie minimalnych sił. W przypadku, gdy właściwości obronne terenu były niewystarczające, budowano kanały, jazy i zapory piętrzące wodę i tworzące rozległe rozlewiska. Pogłębiano również doliny i jary oraz zwiększano kąt nachylenia wzgórz, utrudniając tym samym przemieszczanie się wojsk. Wykorzystywano także szatę roślinną: gęste lasy ograniczały manewry i możliwość wykorzystania ciężkiego sprzętu bojowego, dzięki czemu umocnienia na takich odcinkach mogły mieć lżejszy charakter.

\section{Struktura reliktów krajobrazu militarnego wybranych odcinków Pozycji Pomorskiej}

Poniżej przedstawiona została charakterystyka badanych odcinków, których cechy zestawiono $\mathrm{w}$ tabeli.

\subsection{Odcinek Groß Karzenburg (Sępólno Wielkie, Karz.)}

Jest to najdalej na północ wysunięty fragment Pozycji Pomorskiej. Na północ od niego składała się ona już tylko z fortyfikacji polowych wzmocnionych tobrukami (ringstand 58c). Odcinek rozciaga się od jeziora Cieszęcino do jeziora Bobięcińskie Wielkie. Blokował kilka dogodnych ciaśnin pomiędzy jeziorami oraz ważny szlak komunikacyjny pomiędzy linią GdańskBydgoszcz a Koszalinem (ryc. 2). Był to jedyny z badanych fragmentów pozycji, który w okresie budowy charakteryzował się znacznym udziałem otwartych przestrzeni pól uprawnych. Na linii obrony o długości 8,5 km wybudowano 28 obiektów stałych, w tym 3 cofnięte dość głęboko za drugą linię rowów strzeleckich schrony dowodzenia. Tylko 4 obiekty (położone wzdłuż brzegów jezior) wybudowano w klasie odporności C, pozostałe natomiast należały do klasy B1. Typologicznie dominują obiekty jednosektorowe (13), także w wariancie z pomieszczeniami dla drużyny wypadowej (8) i uzupełnione obiektami dwusektorowymi (2). $\mathrm{Na}$ analizowanym odcinku nie wykonano żadnych stałych obiektów biernych. Ich brak starano się zrekompensować w czasie rozbudowy pozycji polowej przez ulokowanie tu co najmniej 13 biernych obiektów drewniano-ziemnych. Obrona wzmocniona została także jednym cięższym obiektem z trójstrzelnicową kopułą. 3 schrony dowodzenia cofnięto o ok. $1 \mathrm{~km}$ poza linie obronne i rów przeciwpancerny. W dosyć dobrym stanie zachowały się schrony w rejonie Sępólna Wielkiego, ponieważ nie były zdobywane zimą 1945 r. i nie zostały wysadzone po zakończeniu działań wojennych. 


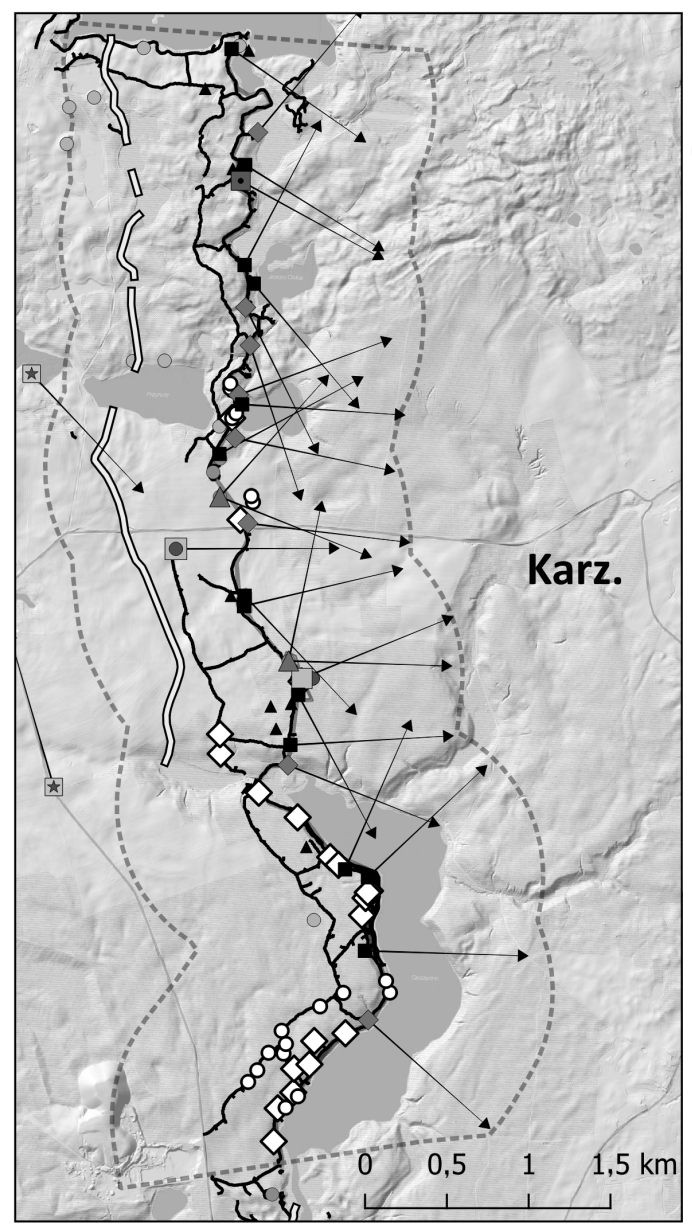

granice odcinka

$\longrightarrow$ kierunki ognia

rów przeciwpancerny

— rowy strzeleckie

obiekty polowe

- typ nieustalony

$\diamond$ schron bierny dołki strzeleckie

- stanowisko $\mathrm{km}$

- stanowisko moździerzowe

- stanowisko PAK

obiekty żelbetowe (29)

- 1-sektorowy za płytą (13)

¿ 1-sektorowy za płytą, dow. (2)

- 1-sektorowy za płytą, dow., obs. (1)

- 1-sektorowy za płyta, druż. pog. (8)

- 1-sektorowy za płytą, obs. pod panc. (1)

$\square$ 1-sektorowy, kopuła 3-strzelnicowa (1)

- 2-sektorowy za płytą (3)

Ryc. 2. Struktura fortyfikacji odcinka Groß Karzenburg (Karz.). Źródto: oprac. własne z wykorzystaniem danych GUGik

Pozycja polowa odcinka składa się $\mathrm{z}$ dwóch ciagłych linii rowów strzeleckich (zachowanych niemal w całości, z wyjątkiem drobnych fragmentów położonych współcześnie na polach uprawnych). Rowy zbudowane zostały z zygzakowato biegnących odcinków o długości ok. $10 \mathrm{~m}$, załamanych pod kątem ok. 30 stopni. Ich wykonanie jest jednak zróżnicowane, co sugeruje pracę różnych ekip. Charakterystyczny jest np. fragment wzdłuż jeziora Cieszęcino, wykonany z bardzo krótkich, cztero-, sześciometrowych odcinków załamanych pod kątem 45-60 stopni i wzbogacony o dodatkowe linie rowów eksponowanych na skarpie jeziornej. Przebieg linii oparto na wszelkich możliwych formach naturalnych: linii brzegowej zbiorników wodnych, przebiegu rowów i cieków oraz obszarów podmokłych. Pierwsza linia rowów wyposażona została w rozmieszczone co kilka metrów przygotowane stanowiska strzeleckie. Linie w terenie leśnym poprowadzono bliżej siebie, w średniej odległości ok. $250 \mathrm{~m}$, odcinkami o długości jedynie $90-150 \mathrm{~m}$. W terenie otwartym dzielące je odległości były już większe, sięgając $420 \mathrm{~m}$. Taki właśnie charakter ma newralgiczny dla obrony odcinek na przedpolu Sępólna Wielkiego, 
zamykający przerwę między jeziorami Kołki i Cieszyno.

Dwie linie obronne połączono rowami łącznikowymi, wykonywanymi zwykle z nieco dłuższych odcinków, załamanych pod mniejszym kątem. Rowy łącznikowe prowadzono średnio co $500 \mathrm{~m}$, przy czym sporadycznie spotyka się je gęściej - w odległości do $350 \mathrm{~m}$.

Większość polowych stanowisk broni maszynowej w obydwu liniach wysunięta została kilkadziesiąt metrów na przedpole, a z główną linią połączono je rowem dobiegowym. Schrony bierne (ziemianki) wykonano w większości na zapleczu pierwszej linii (10 szt. oraz 2 szt. w drugiej linii), łącząc je krótkimi odcinkami rowów. Stanowiska armat przeciwpancernych lokalizowane były natomiast w starannie wybranych, zamaskowanych zadrzewieniem lub ukształtowaniem terenu punktach o dobrym polu ostrzału, zwykle pomiędzy liniami lub nawet za drugą linią. Nie łączono ich z systemem rowów strzeleckich.

W strukturze odcinka można wyróżnić szereg charakterystycznych elementów:

- 2 zespoły obiektów o charakterze węzłów obronnych (po 2 oraz 3 obiekty stałe) wbudowane $\mathrm{w}$ piaszczyste pagórki, połączone wspólną siecią przeszkód i równi ogniowych oraz wspierające się polami ostrzału;

- rów przeciwpancerny biegnący na zapleczu pozycji, łączący dogodnie położone jeziora oraz wykorzystujący rowy melioracyjne;

- rozbudowane pozycje przeciwpancerne ryglujące drogi i wykorzystujące liczne stanowiska polowe dla armat przeciwpancernych;

- cofnięte poza drugą linię obronną obiekty dowodzenia, przystosowane również do prowadzenia jednosektorowego ostrzału skierowanego wzdłuż linii obrony.

Jako jedyny spośród badanych odcinków Groß Karzenburg uległ znaczącym przemianom krajobrazowym wskutek niemal całkowitego zalesienia obszarów, które w okresie funkcjonowania fortyfikacji były raczej otwartym krajobrazem rolniczym, z niewielkimi, izolowanymi płatami leśnymi.

\subsection{Odcinek Demmin (Dyminek, De.)}

Odcinek ten rozciąga się na długości ok. 9,2 km, między jeziorami Bielsko i Dołgie (ryc. 3). Blokował ważną drogę między Szczecinkiem a Człuchowem (dawniej fragment szlaku ze Szczecina do Królewca) oraz linię kolejową ze Szczecinka do Słupska. Linia obrony biegła równinnymi terenami leśnymi i pozbawiona była przeszkód naturalnych. W 1934 r. wybudowano tu 58 żelbetowych schronów o zróżnicowanej odporności i typologii: 19 o odporności B1 i 39 słabszych, o odporności C. W odróżnieniu od poprzedniego odcinka znajduje się tu niewiele obiektów dla drużyny wypadowej (1 obiekt z kazamata pancerna, 3 standardowe i 2 z kopułami dwustrzelnicowymi). Dominują proste, jednosektorowe projekty jednoizbowe (31 sztuk). Charakterystyczną cechą odcinka są liczne obiekty bierne. Zlokalizowano tu 13 ukryć dla drużyny piechoty oraz 5 stanowisk-garaży dla armat przeciwpancernych. Ponieważ ulokowano je na zapleczu linii obronnej i dobrze ukryto we wklęsłych formacjach terenowych, wszystkie wykonane zostały w odporności C. Na odcinku zlokalizowano również 3 obiekty z funkcją obserwacji artylerii $-2 \mathrm{w}$ postaci schronów dwusektorowych ze stanowiskiem obserwatora pod poziomą płytą pancerną oraz $1 \mathrm{z}$ małą kopułą pancerną. W latach 1944 1945 obrona wzmocniona została dwiema liniami transzei (w pierwszej znajdowały się stanowiska strzeleckie) połączonych ze sobą rowami łącznikowymi, podobnie jak na opisywanym powyżej odcinku Groß Kar zenburg. Dwie linie obronne zlokalizowano tu w większych odległościach od siebie (średnio ok. 500 m, minimalnie 250, maksymalnie 880 ). Składały się one $\mathrm{z}$ odcinków o zbliżonej długości, ale ustawionych 


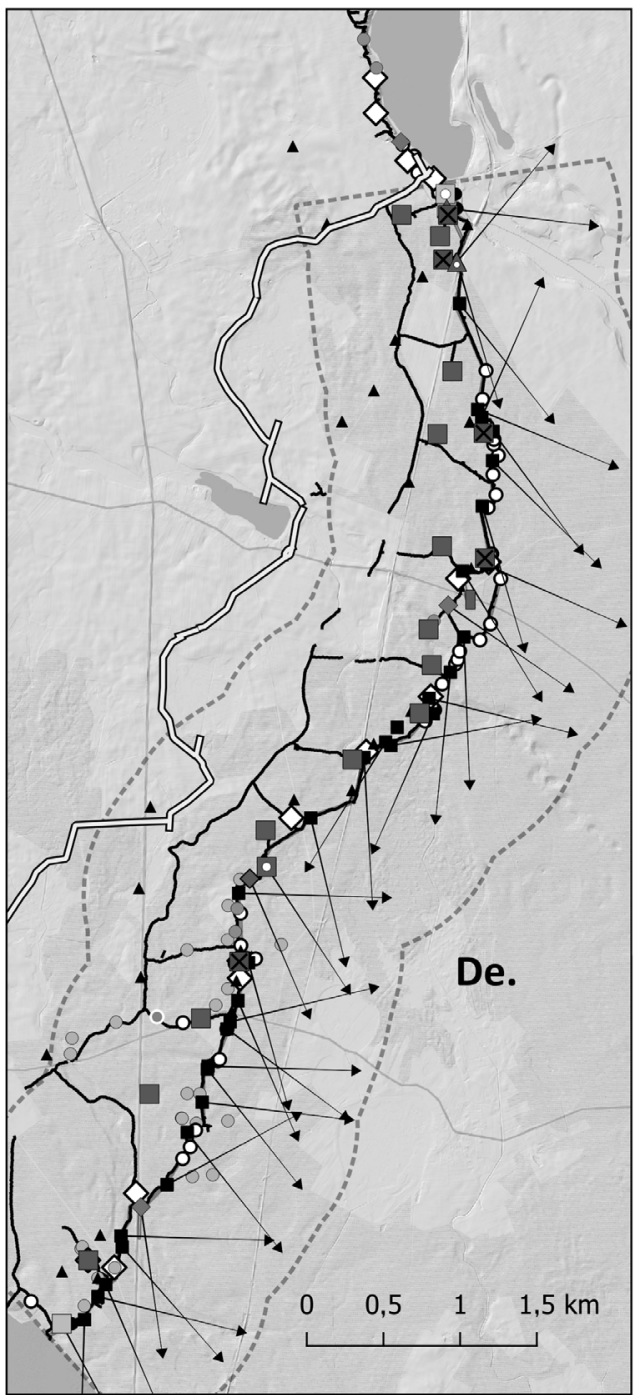

Ryc. 3. Struktura fortyfikacji odcinka Demmin (De.).

Źródło: oprac. własne z wykorzystaniem danych GUGik

względem siebie pod większym kątem, dzięki czemu tworzyły bardziej zębatą linię, co powodowało, że sumaryczna długość rowu, który należało ufortyfikować, była większa niż długość odcinka linii obronnej. Monotonny teren utrudniał rozmieszczenie schronów, dlatego nawet niewielkie pagórki skwapliwie wykorzystano do wmontowania w nie obiektów. Pola ostrzału 17 obiektów poprawiano, formując równie ogniowe, a przedpola co najmniej granice odcinka

$\longrightarrow$ kierunki ognia

rów przeciwpancerny

— rowy strzeleckie

obiekty żelbetowe (58)

$\diamond$ 1-sektorowy w kazamacie, druż. pog. (2)

- 1-sektorowy za płytą (31)

- 1-sektorowy za płytą, druż. pogot. (2)

- 1-sektorowy za płytą, obs. pod kopułą (1)

- 1-sektorowy, kopuła 2-strz., druż. pog. (1)

1-sek., kop. 2-strz., d. pog., obs. pod panc. (1)

A 2-sektorowy za płytą, obs. pod panc. (2)

- bierny dla drużyny piechoty (13)

\ bierny z garażem PAK36 (5)

- zapora ppanc.(1)

obiekty polowe

- typ nieustalony

$\diamond$ schron bierny

dołki strzeleckie

- stanowisko km

- stanowisko moździerzowe

- stanowisko PAK
2 obiektów ufortyfikowane zostały niską siecią kolczastą poprowadzoną w wykopie. Podobnie jak na poprzednio opisanym odcinku rów przeciwpancerny wykonany został na zapleczu drugiej linii obronnej z wykorzystaniem rowów melioracyjnych odwadniających podmokłe łąki wokół jezior Dołgie i Bielsko. Obronę przeciwpancerną wzmocniono natomiast stała przeszkodą, która przegradzała główną droge przecinającą pozycję. Liczne stanowiska 
armat przeciwpancernych (co najmniej 20) zlokalizowano na pozycjach ryglujących przebieg lokalnych dróg (Szczecinek-Biały Bór oraz Biały Bór-Człuchów), a także w strefie pomiędzy liniami obronnymi, podobnie jak na wcześniej opisywanym odcinku nie łącząc ich z systemem rowów.

W pierwszych tygodniach po zdobyciu Pozycji Pomorskiej radzieccy i polscy saperzy wysadzili w powietrze większość znajdujących się na tej linii schronów ${ }^{28}$.

\subsection{Salmer Theerofen - Salmer Theerofen Krähenfließ (Pustelnia - Pustelnia Kanał, STF-STK)}

Kolejne dwa odcinki opisano łącznie, ze względu na ich niewielką długość oraz liczbę obiektów przygotowanych do ich obrony (ryc. 4). Są to odcinki nietypowe, ponieważ wytyczono je, wykorzystując zalesiony i trudno dostępny teren fragmentu doliny Płocicznej, urozmaicony dodatkowo czterema jeziorami rynnowymi. Zabagniona i izolowana od dogodnych szlaków komunikacyjnych przestrzeń sprawiała, że lina Pozycji Pomorskiej miała tu bodaj najsłabiej ufortyfikowany fragment. Jedyny szlak komunikacyjny przecinający ją w tym miejscu na osi wschód-zachód stanowiła podrzędna leśna droga łącząca Człopę i Drawno poprzez przeprawę na rzece przy leśniczówce Salmer Theerofen (Pustelnia). $\mathrm{Z}$ uwagi na niedostępność terenu odcinek ten obsadzono obiektami ubogo, ale bardzo starannie dobierano ich lokalizację. Nieliczne obiekty żelbetowe blokowały systemem ognia jeziorne przesmyki, tworząc węzły obronne ${ }^{29}$. Oba odcinki wyposażono łącznie w jedynie 12 obiektów broniących ok. $6 \mathrm{~km}$ linii obronnej. Tylko 3 stanowiska wykonane zostały w odporności B1, a pozostałe - w odporności C. Aż 11 zlokalizowanych tam stanowisk to schrony jednosektorowe. Wyróżniają się wśród nich 2 obiekty o obniżonej sylwetce

\footnotetext{
${ }^{28}$ D. Piasecki, J. Ellwart, Wat.

${ }^{29}$ K. Michalak, J. Wajda, Fortyfikacje, s. 131-150.
}

z kazamatą pancerną, wzbogacone o odkryte stanowisko dla obserwatora artylerii oraz jedno stanowisko za płytą pancerną z dodatkowym stanowiskiem obserwatora. Wyjątkowym obiektem jest tu rozbudowany schron bierny, który wzmacniał obronę przeprawy w Pustelni i zapewniał schronienie dla co najmniej 2 drużyn, być może pełniąc także funkcję schronu dowodzenia.

Nietypową postać przybrały również na obu analizowanych odcinkach fortyfikacje polowe. Mają one bowiem formę pojedynczej linii rowów strzeleckich, która odcinkami biegnie zachodnią krawędzią rynny doliny Płocicznej lub bardziej na wschód - wysokimi krawędziami położonych wewnątrz niej jezior Piaseczno Duże i Piaseczno Małe. Przy fragmentach, na których linia była cofnięta na zachód, wzdłuż brzegów jezior system wzmacniała sieć dołków strzeleckich przeznaczonych dla 1-2 żołnierzy. Wykonano tam jedynie krótkie odcinki rowów przeciwpancernych przegradzających wąskie przesmyki między jeziorami. Dodatkowym wzmocnieniem obrony odcinka był Kanał Siciński - napełniona wodą budowla hydrotechniczna używana do grawitacyjnego nawadniania łąk na wyżej położonych tarasach doliny. Kanał biegł u podnóża zachodniego zbocza doliny Płocicznej w formie głębokiego rowu o szerokości ok. 5-7 m, odgrodzonego od wschodu wysokim nasypem wału. $\mathrm{Z}$ punktu widzenia taktycznego była to więc budowla przewyższająca parametrami standardowy rów przeciwpancerny. W przesmykach starannie rozlokowano kilka stanowisk PAK, nie wykonano tu jednak żadnych polowych ukryć biernych. $\mathrm{Na}$ zapleczu odcinka zidentyfikowane zostały natomiast liczne ślady, które prawdopodobnie należy wiązać ze zgrupowaniem pojazdów lub artylerii, ale bez badań archeologicznych trudno zidentyfikować zarówno stronę konfliktu, jak i cel takiej koncentracji obiektów polowych. 


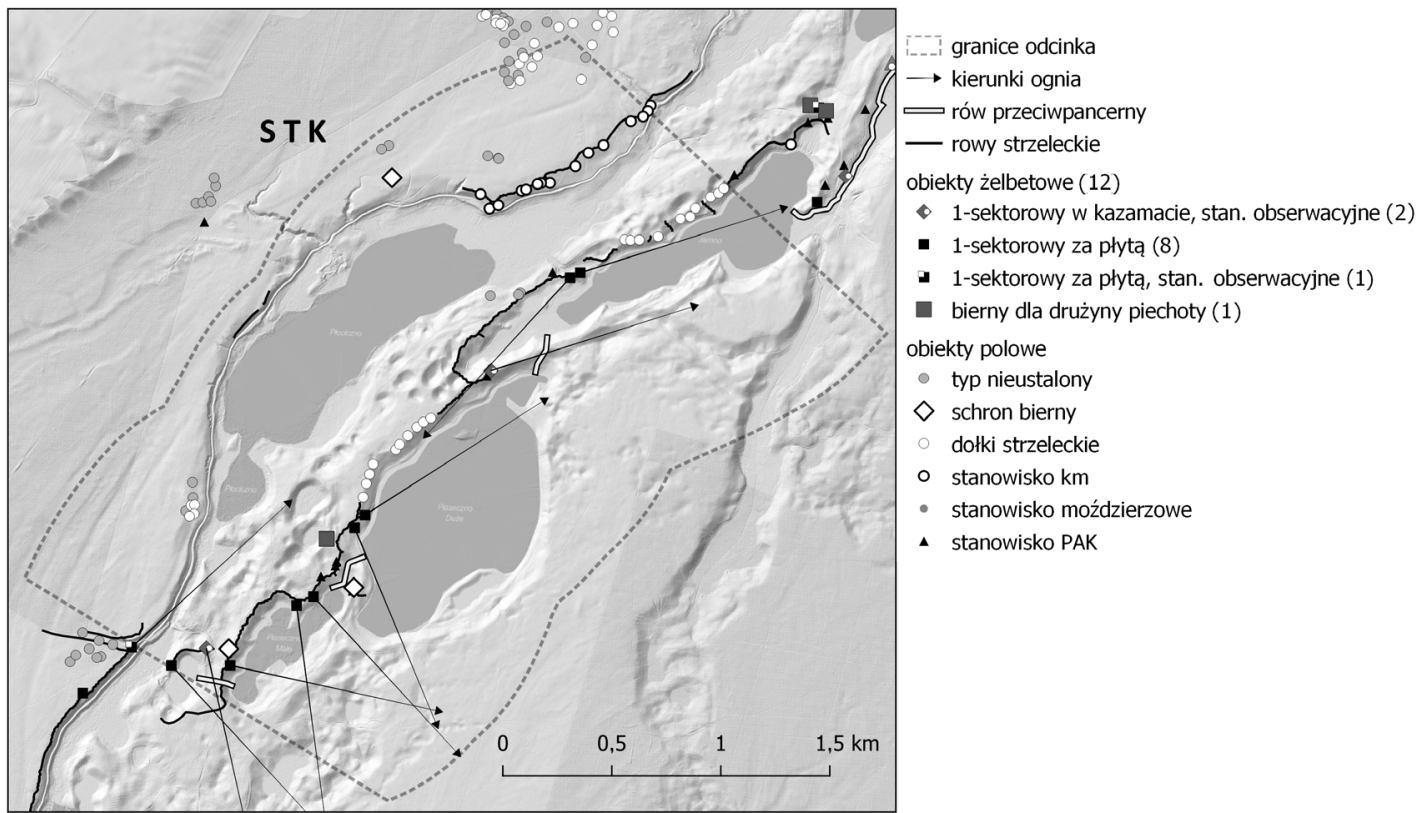

Ryc. 4. Struktura fortyfikacji odcinków Salmer Theerofen Krähenfließ i Salmer Theerofen (STK i STF).

Żródto: oprac. własne z wykorzystaniem danych GUGiK

\section{Struktura Pozycji Pomorskiej na wybranych odcinkach}

Całość linii obronnej Pozycji Pomorskiej składa się z łańcucha stałych obiektów żelbetowych, które uzupełniono mniej lub bardziej skomplikowanym systemem fortyfikacji polowych. Wybrane do badań fragmenty Wału nie oddają całej złożoności i różnorodności rozwiązań; są raczej przykładami rozwiązań typowych dla długich odcinków biegnących wzdłuż formacji terenowych ułatwiających obronę. Najbardziej regularną postać prezentują Groß Karzenburg oraz Demmin: z dwiema ciągłymi liniami rowów strzeleckich połączonych drabinką rowów łącznikowych oraz biegnącym na zapleczu rowem przeciwczołgowym. Odcinki Salmer Theerofen oraz Salmer Theerofen Krähenfließ ukazują z kolei słabszy, uproszczony narys systemu obrony, stosowany w najtrudniejszych terenowo fragmentach linii. Od tego schematu odbiegają przede wszystkim odcinki poprowadzone w sąsiedztwie miast (Szczecinka i Wałcza), gdzie system obronny był o wiele silniejszy i bardziej skomplikowany. Stworzenie wektorowej bazy danych przedstawiającej strukturę pozycji umożliwiło odtworzenie systemu złożonego z bardzo różnorodnych obiektów (ryc. 5). Opracowanie zestawu wskaźników opisujących cechy struktury umożliwiło bardziej obiektywne porównanie odcinków (tab. 1). W przypadku badanych odcinków o podwójnej linii obronnej sumaryczna długość rowów strzeleckich przekraczała długość linii obrony około trzyipółkrotnie, natomiast dla uproszczonego systemu izolowanego odcinka leśno-jeziornego wskaźnik ten był o około połowę niższy. Najwyższą wartość gęstości obiektów stałych (ponad 6 na kilometr) obserwowano na leśnym odcinku Demmin, gdzie z uwagi na brak naturalnych przeszkód linia musiała być jednolicie nasycona środkami obrony na całej długości. Na uwagę zasługuje też znaczna liczba 30 stanowisk broni przeciwpancernej rozmieszczonych na tym odcinku. 


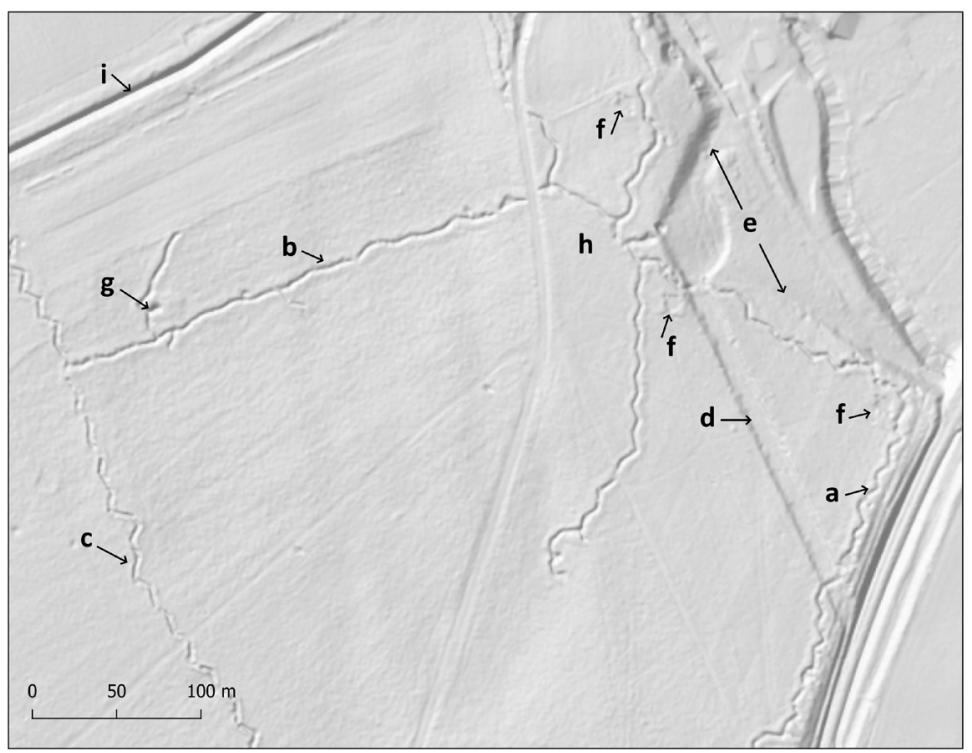

Ryc. 5. Zestawienie powszechnych typów obiektów identyfikowanych na podstawie zobrazowania LiDAR na przykładzie pótnocnego fragmentu odcinka Demmin (De.).

1. rowy strzeleckie, 2. rów łącznikowy, 3. wysadzony obiekt żelbetowy o sygnaturze De.49, 4. stanowisko polowe PAK, 5. wykop dla niskiej sieci przeszkód drutowych, 6. równia ogniowa obiektu De.49, 7. bierny obiekt drewniano-ziemny, 8. rów przeciwpancerny, 9. stanowisko polowe karabinu maszynowego.

Źródto: oprac. własne z wykorzystaniem danych GUGik

Zidentyfikowane na podstawie literatury i obserwacji terenowych azymuty strzelnic umożliwiły odtworzenie systemu sektorów ostrzału na badanych odcinkach. Wygenerowano go za pomocą oprogramowania GIS w postaci wycinków o określonej dla danego typu pancerza szerokości kątowej i zasięgu $1000 \mathrm{~m}$. Umożliwiło to również zobrazowanie fragmentów przedpola linii znajdujących się w wielu nakładających się na siebie sektorach ostrzału (ryc. 6). Na odcinku Groß Karzenburg największą koncentrację sektorów zaplanowano w pobliżu przecinającej go drogi. Fragmenty terenu położone w jej sąsiedztwie znajdowały się w sektorach nawet 8 obiektów, a większość punktów przedpola w tej okolicy znajdowała się w zasięgu 3-4 krzyżujących się sektorów. Typowe dla tego odcinka zespoły obiektów przypominających narysem równi ogniowych i pasów przeszkód dawne forty charakteryzowały się z kolei rozbieżnymi sektorami ostrzału, zaplanowanymi tak, aby w maksymalnym możliwym stopniu pokryć powierzchnię przedpola. System ogniowy dogęszczono dopiero poprzez budowę tobruków i polowych stanowisk karabinów maszynowych. W odcinku Demmin system ogniowy zaplanowano z kolei dość regularnie, z zazębiającymi się na przedpolu sektorami 2-3 obiektów (choć i tu jeden z fragmentów terenu znajdował się w zasięgu 7 obiektów). Równomiernie i gęsto rozmieszczone obiekty, często w przeplatającej się sekwencji: mały schron jednosektorowy, większy obiekt z drużyną pogotowia i obiekt bierny na zapleczu, umożliwiły pokrycie sektorami ostrzału ponad 80 proc. powierzchni przedpola w strefie $1 \mathrm{~km}$. Z kolei na leśno-jeziornych odcinkach Salmer Theerofen i Salmer Theerofen Krähenfließ nieliczne obiekty rozmieszczone grupowo pokrywały 


\begin{tabular}{|c|c|c|c|c|}
\hline$\overline{\mathbf{z}}$ & $\stackrel{\infty}{\circ}$ & fo & 艿 & \\
\hline 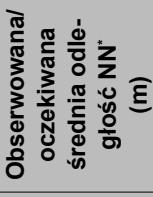 & $\begin{array}{l}\text { o } \\
\text { 骞 }\end{array}$ & 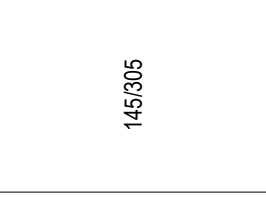 & 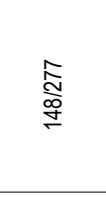 & \\
\hline 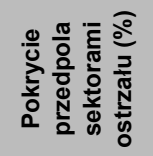 & छे & ळ & F & \\
\hline 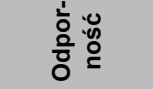 & 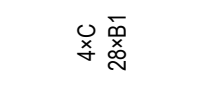 & 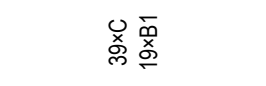 & 容 & \\
\hline 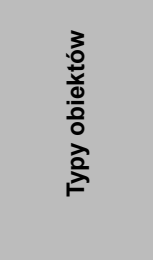 & 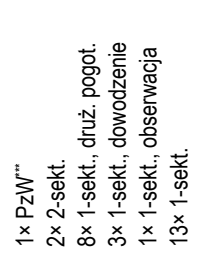 & 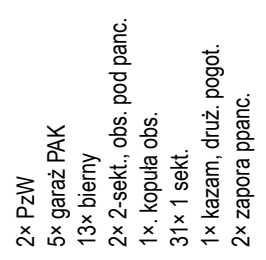 & 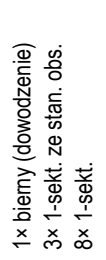 & \\
\hline 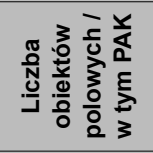 & $\stackrel{\text { D) }}{\stackrel{m}{c}}$ & 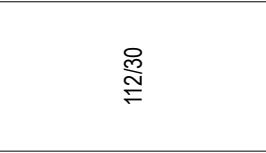 & 莺 & \\
\hline 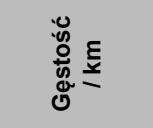 & $\underset{m}{m}$ & ? & 总 & \\
\hline 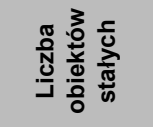 & $\stackrel{\infty}{N}$ & 曲 & $\cong$ & \\
\hline 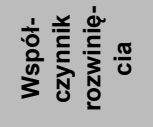 & 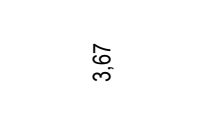 & $\underset{ల}{\widetilde{\sigma}}$ & 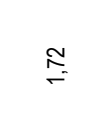 & 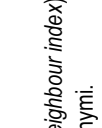 \\
\hline 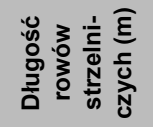 & $\frac{\mathscr{n}}{\dot{m}}$ & 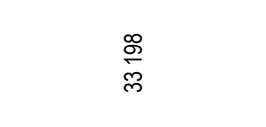 & $\frac{\bar{\sigma}}{6}$ & 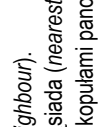 \\
\hline 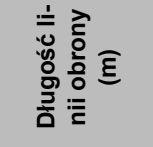 & 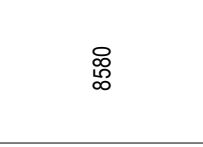 & $\frac{\infty}{\sigma}$ & 怘 & 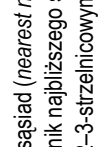 \\
\hline 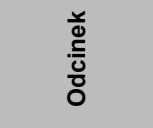 & 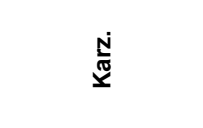 & ه̊ & 詀点 & 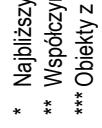 \\
\hline
\end{tabular}




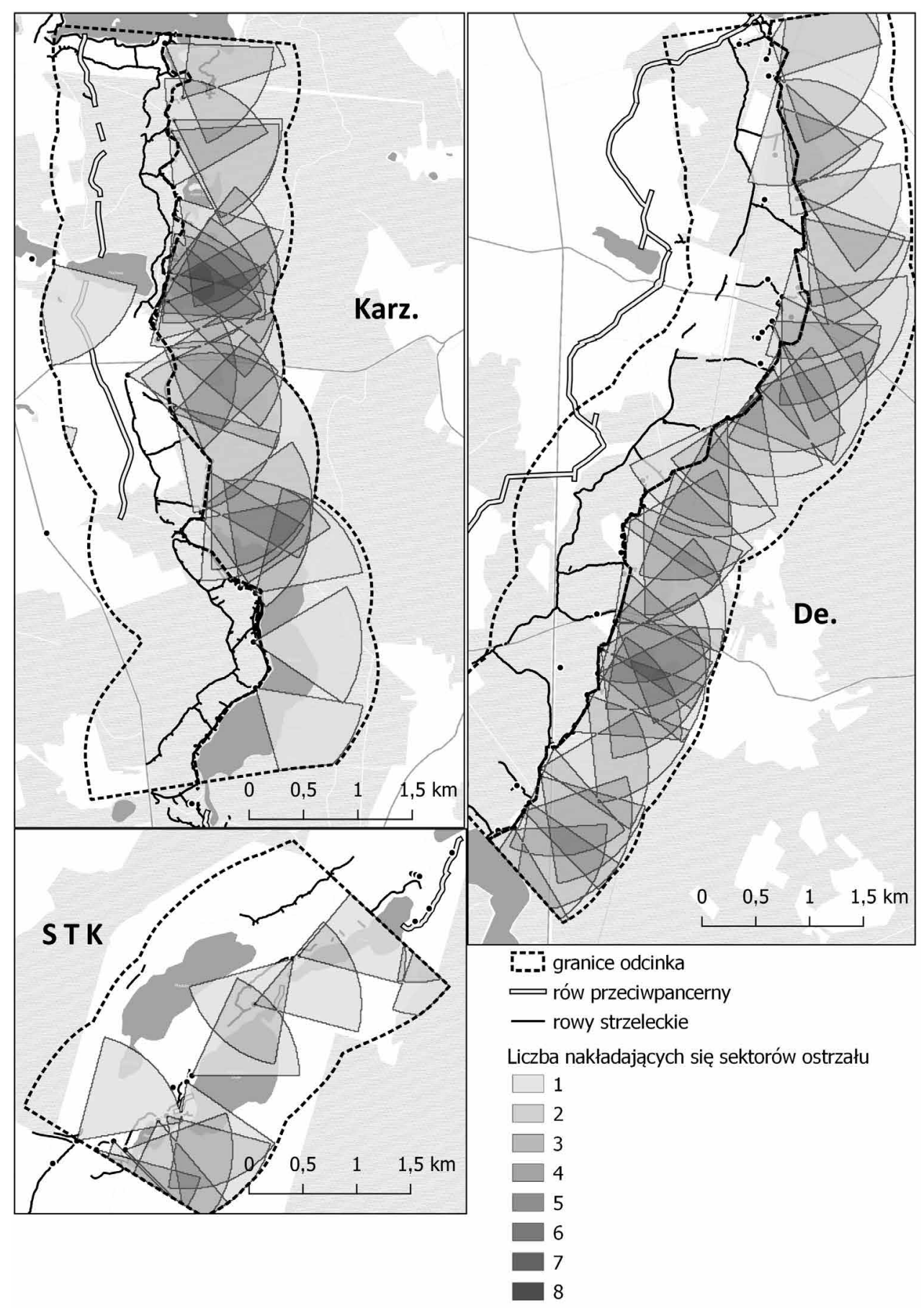

Ryc. 6. Analiza nakładających się sektorów ostrzału z obiektów stałych na badanych odcinkach Pozycji Pomorskiej. Źródto: oprac. własne 
sektorami ostrzału wąskie przesmyki terenu. Jedynie w kluczowym węźle obronnym Pustelni system zagęszczony był miejscowo do 3 sektorów ostrzału.

\section{Podsumowanie}

Krajobraz militarny jest czytelny i zrozumiały zwykle tylko w czasie, w którym pełni swoje funkcje. $Z$ powodu zmian w sztuce wojennej oraz sytuacji politycznej trwa zwykle dość krótko, po czym pozostawia w krajobrazie kulturowym relikty, na podstawie których można dokonać prób oceny i odtworzenia zamysłu jego użytkowników i twórców. Wał Pomorski przetrwał w krajobrazie w postaci bardzo bogatego i zróżnicowanego zespołu reliktów. Większość obiektów betonowych wysadzona zaraz po wojnie jest teraz co prawda w stanie mniej lub bardziej czytelnej ruiny, ale relikty obiektów ziemnych umożliwiają dość precyzyjne odtworzenie zamysłu ich twórców. W przypadku Pozycji Pomorskiej znaczny stopień przetrwania reliktów wynika z uwarunkowań fizjograficznych oraz zmian krajobrazowych, które sprawiły, że większość fortyfikacji znalazła się na terenach zalesionych, które zakonserwowały niejako czytelne ślady systemu umocnień polowych. W przypadku obiektów stałych, choć w większości są

\section{Bibliografia}

Bochenek R., Od muru chińskiego do linii Maginota, Warszawa 1964.

Bogdanowski J., Architektura obronna w krajobrazie Polski, Warszawa 2002.

Chylińska D., Fortyfikacje nowożytne jako element krajobrazu kulturowego na przyktadzie Międzyrzeckiego Rejonu Umocnionego, „Problemy Ekologii Krajobrazu", 18, 2006.

Chylińska D., Nowożytne fortyfikacje state - wybrane problemy zagospodarowania turystycznego, ,Turystyka i Rekreacja”, 2, 2006.

Conflict landscapes and archeology from above, ed. B. Stichelbaut, D. Cowley, Dorchester 2016.

Cudny W., Rouba R., Hotelarstwo jako sposób na rewitalizacje zabytkowych obiektów militarnych zniszczone, wciąż można dokonać uczytelnienia i rekonstrukcji ich funkcji. Dzięki leśnemu pokryciu terenu można więc było odtworzyć niemal kompletny obraz systemu obrony na badanych odcinkach. Stopień zachowania obiektów stałych jest różny. Spora część z nich poza wycięciem pancerzy i elementów metalowych przetrwała w dobrym stanie, zwłaszcza w odcinkach Groß Karzenburg i Demmin. Wykorzystanie zobrazowań modelu terenu i stworzenie bazy danych GIS, poza możliwościami pomiarowymi, daje czytelny obraz dawnego funkcjonowania reliktów jako złożonego systemu obronnego. Wskazuje też na potrzebę opracowania takiej bazy dla całej pozycji umocnionej (m.in. z uwagi na przekształcenia konfiguracji terenu, zwłaszcza w otoczeniu miast, będące skutkiem intensywnych zmian zagospodarowania). Wobec rozproszenia zasobów archiwalnych i wciąż wielu luk we współczesnej wiedzy, zwłaszcza w sferze technicznej i projektowej, wielu uzupełnień wymagają również badania o charakterze dokumentacyjnym. Ma to fundamentalne znaczenie zarówno dla badań o charakterze historyczno-wojskowym, jak i możliwości udostępniania i uczytelniania Pozycji Pomorskiej na potrzeby turystyki. pochodzacych z XIX i XX wieku, „Ochrona Zabytków", 3-4, 2012.

Dudek M., Sadowski J., Fortyfikacje Watu Pomorskiego $w$ Watczu, Gliwice 2006.

The evolving boundaries of defence. An assessment of recent shifts in defence activities, ed. R. Bellais, Emerland, 2014 (Contributions to Conflict Management. Peace Economics and Development, 23).

Fortyfikacje w przestrzeni miast, red. A. Wilkaniec, M. Wichrowski, Poznań 2006.

Golczewski A., Wyzwolenie Pomorza Zachodniego w roku 1945, Poznań 1971.

Hesse R., LiDAR-derived Local Relief Models - a new tool for archeological prospection, „Archeological Prospection”, 17 (2), 2010. 
Kaufmann J.E., Kaufmann H.W., Jurga R.M., Fortyfikacje Trzeciej Rzeszy. Niemieckie umocnienia i systemy obronne w II wojnie światowej, Poznań 2014.

Kiarszys G., Erased landscapes: conflict, memory and post- World War II landscape transformation in western Poland, w: Conflict landscapes and archeology from above, ed. B. Stichelbaut, D. Cowley, Dorchester 2016.

Kiarszys G., Banaszek Ł., Dostrzec i zrozumieć. Porównanie wybranych metod wizualizacji danych ALS wykorzystywanych $w$ archeologii, „Folia Praehistorica Posnaniensia”, 22, 2017.

Klupsz L., Miejsce fortyfikacji we wspótczesnych aglomeracjach, w: Fortyfikacje w przestrzeni miast, red. A. Wilkaniec, M. Wichrowski, Poznań 2006.

Kupiec M., Przemiany krajobrazowe wybranych dolin rzecznych $w$ Polsce Pótnocno-Zachodniej od XIX do początków XXI wieku, Szczecin 2014.

Kupiec M., Dusza E., Potencjat turystyczny obiektów zwiazanych z dawna Pozycja Pomorska, „Problemy Ekologii Krajobrazu”, 34, 2012.

McGarigal K., Cushman S.A., Ene E., FRAGSTATS: Spatial Pattern Analysis Program for Categorical and Continuous Maps, „UMass Landscape Ecology Lab” (http://www.umass.edu/landeco/research/fragstats/ fragstats.html, dostęp: 7 maja 2020).

Marek A., Marszałek Ł., Obiekty militarne jako element krajobrazu kulturowego Pótwyspu Helskiego, „Studia z Geografii Politycznej i Historycznej”, 7, 2018.

Michalak K., Wajda J., Fortyfikacje Pozycji Pomorskiej jako walor kulturowy Drawieńskiego Parku Narodowego, „Nadwarciański Rocznik Historyczno-Archiwalny", 18, 2011.

Miniewicz J., Perzyk B., Wat Pomorski, Warszawa 1997.

Murawski E., Bój o Pomorze. Ostatnie walki obronne na wschodzie, Oświęcim 2016.
Myga-Piątek U., Krajobrazy kulturowe. Aspekty ewolucyjne i typologiczne, Katowice 2012.

Perzyk B., Inwentaryzacja, waloryzacja i wytyczne do programu ochrony fortyfikacji Watu Pomorskiego w granicach woj. zachodniopomorskiego, [b.m.w.] 2001, mps, Zachodniopomorski Wojewódzki Konserwator Zabytków.

Piasecki D., Ellwart J., Wat Pomorski, Gdynia 2014.

Pieńkowski P., Podlasiński M., Changes in forest cover of Szczecin Lowland from the $16^{\text {th }}$ to the end of the $20^{\text {th }}$ century, in relation to soil cover, „Electronic Journal of Polish Agricultural Universities. Series: Forestry”, 5 (2), 2002.

Plit J., Krajobrazy kulturowe Polski i ich przemiany, Warszawa 2016 (Prace Geograficzne, 253).

Ramowy Program Ochrony i Rewitalizacji Zespotu Historyczno-Krajobrazowego Twierdzy Kraków, Kraków 2006, załącznik do uchwały Rady Miasta Krakowa $\mathrm{Nr}$ CXIX/1294/06 z 25 października 2006 r.

Sabien S., Pierwszy etap budowy Pozycji Pomorskiej $w$ świetle dokumentów z federalnego archiwum wojskowego we Freiburgu, „Cztery Historie”, 1 (2), 2015.

Środulska-Wielgus J., Wielgus K., Waloryzacja jako podstawa turystycznego udostępnienia krajobrazu warownego, „Przestrzeń i Forma”, 26, 2016.

Woodward R., Looking at military landscapes: Definitions and approaches, w: The evolving boundaries of defence. An assessment of recent shifts in defence activities, ed. R. Bellais, Emerland, 2014 (Contributions to Conflict Management. Peace Economics and Development, 23).

Woodward R., Military landscapes: Agendas and approaches for future research, „Progress in Human Geography”, 38 (1), 2014.

\section{The structure of the military landscape of the second war fortified position on the example of selected sections of the Pomeranian Position (Pommernstellung)}

\section{Summary}

Military landscapes are a specific type of cultural landscapes, resulting from transformations of landscape components (land use structures, relief, hydrology) and the introduction of a number of infrastructural objects (obstacles, field and permanent fortification, engineering facilities) to fulfill a specific military function. Fortified areas most often served their original function for a short time, after which military elements in the landscape were abandoned or removed. Therefore, in the contemporary landscape we deal with relics of military landscapes rather than their full form. The original spatial structure of military landscapes can be reconstructed on the basis of archival cartographic materials and documents, field inventory, analysis of aerial photographs and terrain models from airborne laser scanning. In the cultural landscape of Pomerania, one can distinguish a number of elements related to the Pomeranian Position (Pommernstellung) built by Germany in the 1930s. They have special historical and landscape value due to the close 
connection between shape of the position and local physiography conditions and the variety of identifiable relics. The paper presents an attempt to reconstruct the full, original structure of fragments of the Pomeranian Position in its final form from spring 1945 based on available materials and field works.

Michał Kupiec - pracownik Instytutu Gospodarki Przestrzennej i Geografii Społeczno-Ekonomicznej Uniwersytetu Szczecińskiego. Zajmuje się badaniami krajobrazowymi - gtównie analizami przekształceń krajobrazu kulturowego, badaniem struktury krajobrazu, tworzeniem baz danych i inwentaryzacji krajobrazowych. Interesuje się również krajobrazami militarnymi

(michal.kupiec@usz.edu.pl)

Magda Olejniczak - doktorantka na Wydziale Nauk Ścisłych i Przyrodniczych Uniwersytetu Szczecińskiego. Obecnie zajmuje się problematyką militarnego krajobrazu kulturowego. Pozostałe zainteresowania badawcze: turystyka kulturowa ze szczególnym uwzględnieniem turystyki militarnej i przemysłowej, a także rewitalizacja i rewaloryzacja militarnego i przemysłowego dziedzictwa kulturowego

(magdalena.olejniczak90@gmail.com)

Michał Kupiec - employee of the Institute of Spatial Management and Socio-Economic Geography of the University of Szczecin. He deals with landscape research: mainly analyzes of cultural landscape transformations, landscape structure research, database creation and landscape inventories. He is also interested in military landscapes

(michal.kupiec@usz.edu.pl)

Magda Olejniczak - PhD student at the Faculty of Sciences and Natural Sciences of the University of Szczecin. Currently deals with the issues of the military cultural landscape. Other research interest: cultural tourism, with particular emphasis on military and industrial tourism; revitalization and revaluation of military and industrial cultural heritage

(magdalena.olejniczak90@gmail.com) 